DOI: $10.14451 / 2.133 .29$

\title{
ПОНЯТИЕ ОРУЖИЯ КАК ТОВАРА В МЕЖДУНАРОДНОМ ТОВАРООБОРОТЕ
}

\author{
(c) 2019 Кутафина Виолетта Валерьевна \\ аспирант \\ Московский государственный юридический университет \\ им. О.Е. Кутафина (МГЮА), Россия, Москва \\ E-mail: kviolettav20@yandex.ru
}

Настоящая статья посвящена определению понятия оружия в международном публичном праве. Автором анализируются нормы российского законодательства и международного права по вопросу международной торговли оружием. Отмечается, что использование положений Международного договора о торговле оружием, разработанных Организацией Объединенных Наций, позволит устранить пробелы и противоречия в национальном законодательстве об оружии и практике государств по разработке и поставке объектов военного назначения.

Ключевые слова: оружие, вооружение, военно-техническое сотрудничество, международный оборот оружия

Вооруженные конфликты внутригосударственного и международного характера, терроризм, а также иные формы применения силового воздействия составляют основную угрозу миру и международной безопасности. Основное средство применения силового воздействия для государств на сегодняшний день - это оружие. В праве международной безопасности, посвященному глобальному изучению вооруженных конфликтов, не уделяется достаточного внимания одному из древнейших видов человеческой деятельности - вооружению народов и государств, а также оружию как средству и методу силового воздействия.

Отметим, что вооружением занимались и занимаются народы и государства во времена всех цивилизаций, не только во время войн, но и в мирное время. Следует согласится с мнением Куликова Ю.В. о том, что вооружение, как вид деятельности народов и государств должно занять свое место среди иных видов деятельности в пирамиде «История видов человеческой деятельности» [1, с.22]. Выделение «военного дела государства», как вида деятельности, вместо «войн и революций» более обосновано, так как данное понятие охватывает как ведение войн, так и разного рода подготовку к вооруженным действиям.

В связи с конфронтацией государств и развитием блокового формата отношений на международной арене возрастает спрос на оборонно-промышленные товары. Основной задачей развития оборонно-промышленного комплек- са Российской Федерации является не только способность удовлетворить потребности вооруженных сил, но и обеспечить эффективное функционирование оборонно-промышленного комплекса, как высокотехнологичного многопрофильного сектора экономики страны, обеспечить стратегическое присутствие Российской Федерации на мировых рынках высокотехнологичной продукции и услуг [2].

От уровня развития военного дела государства зависит его положение на международной арене. В связи с этим, в статьях государственного бюджета постоянно растут военные расходы на вооружение. Согласно данным, опубликованным Стокгольмским международным институтом исследований проблем мира (SIPRI), в 2017 объём продаж вооружений и военных услуг крупнейшими военно-промышленными компаниями составил 398.2 млрд. долларов [3].

Ученые Протопопов А.С. и Шпаковская М.А., отмечают, что суждения юристов международников и политиков о том, что рост вооружений служит выходом из экономических затруднений государств несостоятельны [4].

На этот счет, бывший министр иностранных дел Швеции Альва Мюрдаль в своей книге «Игра разоружения: Как США и Россия проводят гонку вооружения» писал: «гонка вооружений будет и дальше снижать долю расходов на социальные нужды и тем самым способствует дальнейшему спаду экономического роста» [5]. История экономического развития показывает, что гонка вооружений и увеличение военных расходов 
негативно сказываются на социальной сфере и влекут увеличение налогового бремени для граждан и бизнеса, безработицу, быстрое сокращение ассигнований, субсидий на социальные нужды.

На наш взгляд, сущность и содержание вооружения как вида человеческой деятельности влияет на определение понятийного аппарата и правовое регулирование оборота оружия как на национальном уровне, так и на международной арене.

Так, в последнем издании Советской военной энциклопедии термин «вооружение» определяется как процесс качественного развития и количественного роста военной техники в государстве, а также оснащения ею вооруженных сил. Включает планирование развития военной техники, ее разработку, производство и оснащение ею вооруженных сил. Организуется с учетом рекомендаций теории вооружения [6].

В виду развития общества и общественных отношений на сегодняшний день в этот «процесс» включены также иные виды человеческой деятельности, тесно связанные с логикой так называемого «жизненного цикла оружия»:

- планирование создания оружия;

- конструирование оружия;

- изготовление и испытание опытного образца оружия - третья совокупность действий вооружения;

- производство оружия - второй и решающий этап совокупности действий организации вооружения как вида человеческой деятельности;

- накапливание запаса оружия в государстве, хранение изготовленного и утилизация устаревшего оружия;

- продажа произведенного оружия - совокупность действий по торговле оружием: а) на внутреннем рынке; б) на мировом рынке. Торговля оружием на внутренних и мировых рынках оружия является последней, завершающей стадией совокупности действий вооружения как вида человеческой деятельности [1, с.26].

Процесс формулирования понятия «оружие» и его нормативного закрепления довольно сложен и неоднозначен. На наш взгляд, именно определение и закрепление данного понятия в нормативно-правовых актах Российской Федерации должно предшествовать регулированию отношений, связанных с оружием. Для определения понятия оружия воспользуемся несколь- кими авторитетными мнениями. В толковом словаре Владимира Ивановича Даля «оружие» определяется как «всякое средство, приспособленное, технически пригодное для нападения или защиты» [7]. В Большой Советской энциклопедии под оружием понимается общее название устройств и средств, применимых в вооруженной борьбе для уничтожения живой силы противника, его техники и сооружений [8]. Данные понятия широко и неоднозначно обозначают круг предметов, которые возможно отнести к понятию оружия. В связи с этим возникают проблемы в регулировании оборота оружия как товара на международном рынке.

Действующий Федеральный закон Российской Федерации «Об оружии» от 13.12.1996 № 150-ФЗ (далее - Закон «Об оружии») содержит следующее определение оружия - «устройства и предметы, конструктивно предназначенные для поражения живой или иной цели, подачи сигналов» [9]. Данное определение расширяет понятие оружия, включая в него устройства и предметы, предназначенные для подачи сигналов.

В научной литературе определению оружия также уделено внимание, например, Шумилов В.М. определяет оружие как общее название устройств, предметов и средств, конструктивно предназначенных для убийства людей и животных и/или выведения из строя техники и сооружений сторон, вольно либо невольно участвующих в конфликте с применением оружия.

Представленные мнения, в целом ограничивают понятие оружия средствами, предметами, устройствами, которые созданы для поражения цели. Но в науке международного права существует и более широкое определение понятия оружия. Например, понятие оружия в рамках международного гуманитарного права как раздела международного публичного права определяется как одно из средств ведения войны, которые применяются вооруженными силами воюющих сторон для нанесения вреда и поражения противника.

В Федеральном законе Российской Федерации от 19.07.1998 № 114-Ф3 «О военно-техническом сотрудничестве Российской Федерации с иностранными государствами» употребляется понятие «продукция военного назначения», под которой понимается «вооружение, военная техника, работы, услуги, результаты интеллектуальной деятельности, в том числе исключительные права на них (интеллектуальная собственность) 
и информация в военно-технической области...» [10].

Очевидно, что понятие «продукция военного назначения» гораздо шире понятия «оружие» в Законе «Об оружии». К продукции военного назначения вышеупомянутый федеральный закон относит широкий перечень объектов: от вооружения и военной техники, систем связи и взрывчатых веществ, специальных сооружений для применения военной техники, оборудования для ремонта и модернизации военной техники до документации, которая регламентирует создание, производство эксплуатацию, боевое применение, модернизацию, ремонт и уничтожение (утилизацию) продукции военного назначения; а также результаты научно-исследовательских и опытно-конструкторских работ по созданию, модернизации и уничтожению вооружения и военной техники; услуги инвестиционного, маркетингового, рекламного и иного характера в области военно-технического сотрудничества; ремонт вооружения и военной техники и иная деятельность в области военно-технического сотрудничества, не противоречащая законодательству Российской Федерации.

На наш взгляд, в Федеральном законе Российской Федерации «О военно-техническом сотрудничестве Российской Федерации с иностранными государствами» исчерпывающе описана продукция военного назначения, как объект, который требует особого регулирования на внутригосударственном и международном уровне.

В Международном кодексе поведения в отношении поставок оружия от 2000 г. использован комплексный подход в формулировании понятия оружия, авторы попытались путем перечисления военно-технологического оснащения государств в понятие «оружие» включить не только все виды оружия и боевой техники. Существенно важным дополнением к вышеуказанным понятиям оружия, на наш взгляд, являются:

1) закрепление понятия компонентов и систем доставки оружия, к которым относятся: боевые танки, боевые бронированные машины, военные самолеты, артиллерийские системы, военные вертолеты, ракеты, имущество военизированной полиции, минометы, пулеметы и автоматы, винтовки, пистолеты, противотанковые орудия, мины, гранаты, кассетные бомбы и все виды боеприпасов;

2) выделение «чувствительных» техноло- гий и технологий двойного назначения, например, таких как шифровальная техника, суперкомпьютеры, газовые турбины и др.

3) включение подготовки военнослужащих и сотрудников органов безопасности, включая передачу опыта, знаний или навыков применения такого оружия, боевой техники, компонентов и «чувствительных» технологий в понятие оружие. То есть в данном случае, товаром является компетенции личного состава вооруженных сил того или иного государства по использованию объектов военного назначения [11].

Тем самым, Международный кодекс поведения в отношении поставок оружия обозначил и конкретизировал тот перечень объектов, которые подпадают под понятие оружия.

Стоит отметить, что 2 апреля 2013 года на заседании Генеральной Ассамблеи ООН был принят Международный договор о торговле оружием (сокращенно «МДТО»), который ограничил виды вооружений, а именно отнес к объектам торговли оружием: а) боевые танки; б) боевые бронированные машины; в) артиллерийские системы большого калибра; г) боевые самолеты; д) боевые вертолеты; е) военные корабли; ж) ракеты и ракетные пусковые установки; и з) стрелковое оружие и легкие вооружения [12].

Таким образом, МДТО не только конкретизировал, но и существенно сузил круг объектов, которые подпадают под понятие оружия и могут быть предметом международных торговых отношений.

Следует обратить внимание, что в понятие оружия, которое дано в МДТО, не включены существенно важные объекты военного назначения: системы связи и взрывчатые вещества; «чувствительные» технологии и технологии двойного назначения; подготовка военнослужащих и сотрудников органов безопасности, включая передачу опыта, знаний или навыков применения оружия.

Полагаем, что исключение из международного регулирования оборота оружия указанных объектов военного назначения может способствовать их бесконтрольному распространению и служить угрозой миру и международной безопасности.

Следует согласиться с Пермяковой Э.Ш., Тюриной Н.Е., что перечень объектов, которые относятся к оружию неполный, с учетом цели Договора. Ученые-международники отмечают, что преамбула международного договора в качестве 
одной из целей закрепляет регулирование и пресечение несанкционированного конечного использования оружия, в том числе для совершения террористических актов. Использование взрывчатых веществ - один из способов совершения террористических актов [13].

Международный договор о торговле оружием и его разработка - огромный шаг международного сообщества к разрешению проблем, связанных с торговлей оружием. Данный договор очертил сферу регулирования, признав, что отсутствие согласованных международных стандартов в отношении торговли обычным оружием создает угрозу миру, примирению, безопасности, стабильности и устойчивому социально-экономическому развитию.

На наш взгляд, международный договор о торговле оружием устранил недостатки понятийного аппарата национального и международно-правового регулирования по вопросу понимания и оборота оружия, сформулировал единый подход в определении термина «оружие».

Имплементация положений указанного международного акта в национальное законодательство, использование его понятийного аппарата и подходов в развитии международных отношений позволит устранить пробелы в международно-правовом регулировании отношений государств, предметом которых является вооружение, поставки оружия, торговля оружием. Толкование данного термина как в узком, так и в широком смыслах является одной из главных задач законодателя во внутригосударственном праве и субъектов международного нормотворчества.

Полагаем, что отсутствие закрепленных международных стандартов в сфере вооружения может привести к росту преступлений, увеличению террористических актов и нелегального оборота оружия в мире. Несмотря на то, что государства осуществляют нормативно-правовое регулирование поставок оружия как во внутреннем гражданском обороте, так и между собой, единая система регулирования торговли оружием и предотвращения незаконного оборота оружия в международном праве находится на этапе своего становления.

\section{Библиографический список}

1. Куликов В.А. История оружия и вооружения народов и государств с древнейших времен до наших дней: [монография] / В.А. Куликов; Вост. ин-т экономики, гуманитар. наук, упр. и права. Уфа: Вост. ун-т, 2003 (Тип. Изд-ва).

2. Военная доктрина Российской Федерации, утв. Президентом РФ 25.12.2014 № Пр-2976 // СПС «Консультант Плюс».

3. Пресс-релиз EMBARGO от 10 декабря 2018 г. // URL: https://www.sipri.org/sites/default/files/2018-12/2018_ sipri_top_100_press_release_rus (дата обращения: 30.09.2019).

4. Протопопов А.С., Шиаковская М.А. Проблемы разоружения в конце XX- начале XXI веков А.С. Протопопов, М.А. Шпаковская. Вестник РУдН, серия Международные отношения, 2014. № 2. С.178.

5. Myrdal Alva «The game of Disarmament: How the United States and Russia run the arms races» Phanteon Books, 1976. P 60.

6. Советская военная энциклопедия М.: Воениздат, 1976-1980. Т.2 Вавилон Гражданская война в Северной Америке. 1976. С. 266.

7. Даль В.И. Толковый словарь живого великого русского языка. Т.ІІ: И-О. СПб.; М., 1881. С.715.

8. Большая советская энциклопедия: в 30 т. / гл. ред. А. М. Прохоров. 3-е изд. М.: Сов. энцикл., 1969-1978. 30 т.

9. Федеральный закон от 13.12.1996 № 150-ФЗ «Об оружии» // СЗ РФ. 16.12.1996. № 51. С. 5681.

10. Федеральный закон от 19.07.1998 № 114-Ф3 «О военно-техническом сотрудничестве Российской Федерации с иностранными государствами» // СЗ РФ. 27.07.1998. № 30. С. 3610.

11. Письмо Постоянного представителя Нидерландов при Организации Объединенных Наций от 30.01 .2003 на имя Генерального секретаря ООН N A/57/724 // URL: https://documents-ddsny.un.org/doc/UNDOC/GEN/ N03/240/46/PDF/N0324046 (дата обращения 30.09.2019).

12. Договор о торговле оружием ООН от 2014 г. // URL: https://unoda-web.s3-accelerate.amazonaws.com/wpcontent/uploads/2013/06/2.pdf (дата обращения 30.09.2019).

13. Пермякова Э.Ш., Тюрина Н.Е. Международный договор о торговле оружием // Евразийский юридический журнал. 2014. № 12 (79). С.53-55. 